\title{
A Cosmological Crisis?: A Review of Nasser Zakariya, The Final Story: Science, Myth, and Beginnings
}

Ken Baskin

Correspondence | Ken Baskin, baskinman47@yahoo.com

Citation | Baskin, K. (2019) A Cosmological Crisis?: A Review of Nasser Zakarayia, The Final Story: Science, Myth, and Beginnings (University of Chicago Press, 2017), Journal of Big History, III (4); 171 - 176.

DOI | https://doi.org/10.22339/jbh.v3i4.3477

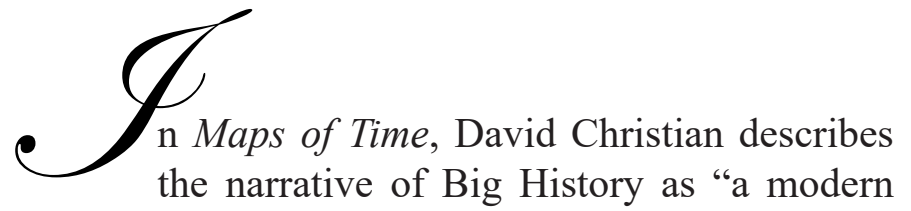

'Dreaming' - a coherent account of how we were created and how we fit into the scheme of things." Yet, he adds more recently, that narrative "is far from complete, and ... may need to incorporate the insights of older origin stories about how to live well and how to live sustainably." 2 The discussion of this narrative and how to strengthen it has swirled through every IBHA conference since the first, in 2012. More recently, it was the subject of a special issue of the IBHA Journal. For anyone who wants to understand this discussion more fully, I can't recommend Nasser Zakariya's A Final Story highly enough.

In his book, Zakariya explores the history of our origin story. (Like most writers on the subject, Zakariya refers to is as a "cosmology," which I'll be using in this essay.) He begins with the natural historians of the first half of the nineteenth century, who applied the growing body of scientific knowledge to construct a world history, intellectual pioneers such as John Herschel and Mary Sommerville. By the end of that century, the gallery of contributors reads like a Who's Who of progressive scientific thought, including Comte and Lord Kelvin, Julian Huxley and Einstein, E.O. Wilson and Carl Sagan. Zakariya tells the story behind the story with a wide-view, sometimes-critical perspective. For example, he documents the limitations of the scientific materialism at the heart of the evolutionary epic and the all-butinevitable confusions that emerged in the attempts of Sagan or Neil deGrasse Tyson to popularize its complex scientific issues on TV.

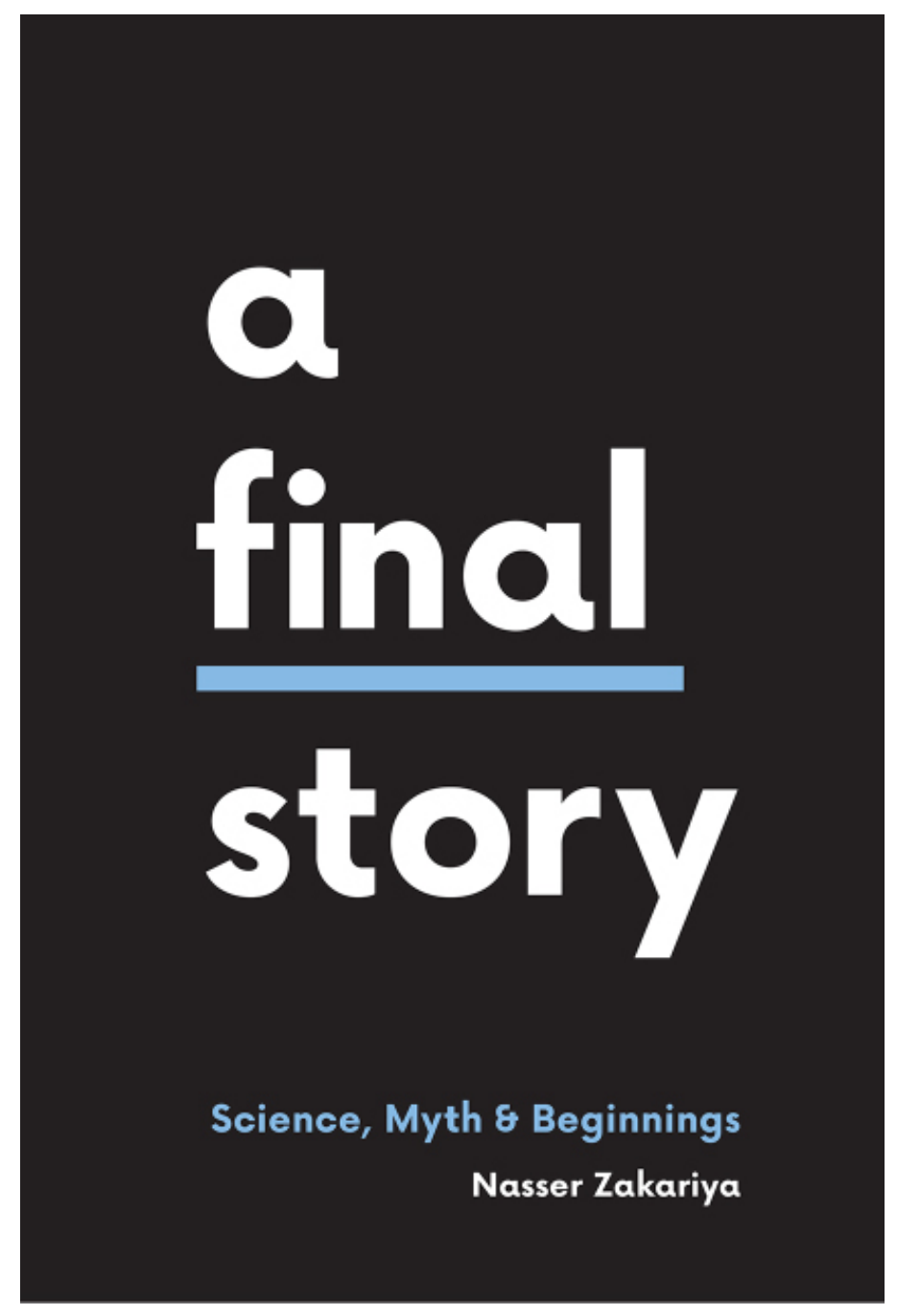

Zakariya's treatment is solid, so much so that, rather than selectively explore parts of his book, I recommend letting A Final Story speak for itself. However, reading the book, I was struck by the need to clarify the concept of a "cosmology," especially for those of us, who, like Christian, want to develop a narrative 
that can meet the needs of people across the globe in the $21^{\text {st }}$ Century. To do so, we need to understand the functions that cosmologies have always fulfilled and present the Big History cosmology in a way that is both accessible and acceptable. Otherwise, we could craft a story that will only work for ourselves.

At first look, this confusion seems to be a classic case of dueling definitions. From a scientific, Western outlook, cosmology is "the science of the origin and evolution of our Universe." 3 Yet, the word can also have a more mythic meaning, as in Joseph Campbell's definition, "an image of the cosmos that will ... explain everything that you come into contact with in the universe around you." Zakariya's book is largely about current attempts to bridge these definitions, as when Wilson insists that this "evolutionary epic is probably the best myth we will ever have." 5

Similarly, Christian presents a more mythic version of Big History's scientific cosmology:

a shared map of understanding that shows members of the community their place in a rich, beautiful, and sometimes terrifying universe: This is what you are; this is where you came from; this is who existed before you were born; this is the whole thing of which you are a small part; these are the responsibilities and challenges of living in a community of others like yourself. ${ }^{6}$

The key difference between these two definitions is not the story they tell, but the way that story is interpreted. Proponents of the scientific cosmology focus on the literal truth of their narrative; so, as Zakariya points out, they often present the BigBang-to-the-present narrative as superior to older cosmologies because it is based on fact, images of our Universe and mathematical computations, rather than mythic fictions. Ironically, astrophysicist Pedro Ferreira undercuts this claim when he notes, "Maybe more than in any other field of physics, cosmologists construct fantasy worlds which they hope may have some bearing on what we observe." "For proponents of a more mythic cosmology, the narrative is a way of examining society and how we are to live in it. Since the time of Ancient Egypt and Sumer, cosmologies applied the order that observers found in the skies to society. I'd suggest that these cosmologies reflect the symbolic orders with which members of any society approach their worlds, including their interpretations of the skies, in a way that enables them to apply that order, with its underlying assumptions, to their societies. As John Lundwall points out, cosmologies are epistemological, teaching members of any society how to know their worlds. ${ }^{8}$

For this reason, cosmologies can have survival value, especially when societies face existential crises, as our global society does today. For example, c. 576 BCE, the Assyrians conquered Judah (the southern Israelite kingdom), destroyed Solomon's Temple, and exiled much of its elite to Babylon. A similar conquest a century-and-a-half earlier had destroyed Israel (the northern kingdom). Yet, instead of accepting that their God had forsaken them, as people in most contemporary societies would have, ${ }^{9}$ the society's elite reinvented its cosmology, by editing its mythic texts, so that their One God had not abandoned them, but was punishing them for not worshipping Him alone. ${ }^{10}$ This interpretation would sit at the heart of their cosmology and His Chosen People's covenant with the One True God, which taught them that their God was so powerful that $\mathrm{He}$ could use the Israelites' greatest enemies as tools to enforce His covenant with them. In many ways, then the Hebrew Bible would function as an Israelite Big History, from God's creation of the world to the return from Babylonian exile. It allowed these Israelites to learn a different way of thinking about the world, developing a strong sense of responsibility in situations where they might seem victimized and providing many of the fundamental assumptions that would enable them to survive repeated pogroms and expulsions. 
The same sort of reinterpretation would occur early in Modernity, leading to the West's current scientific cosmology. For the West, the existential crisis would combine the collapse of the feudal system after the Black Death, where about a half of its population died between 1347 and 1351, and the horror of a centuryand-a-half of religious war, where Protestants and Catholics slaughtered each other to prove who knew the proper way to worship the Prince of Peace ${ }^{11}$. The two foremost reinterpreters were Francis Bacon and René Descartes. In response to these wars, both sought to create a form of science that would produce peace, order, and certainty.

This reinterpretation would integrate elements of Christian thought into the discoveries of early scientists such as Kepler, Copernicus, and Galileo. Copernicus described it as a "Clockwork Universe," and Galileo concluded that God had created the world as a "Second Book," written in the language of mathematics. ${ }^{12}$ This image of the Universe as a machine became so firmly fixed in this emerging cosmology that the philosophy of Descartes and the physics of Newton would combine to picture our world as composed of dead, passive matter moving deterministically under the influence of Universal Laws of Nature. And because these laws were created by God, He was the source of everything that happened.

What Bacon and Descartes would do was to reinterpret key elements of Christian thought as a grounding for this emerging understanding of the cosmos. Bacon drew on the Arthurian quest myth, where the king's knights would sacrifice their lives to find the Holy Grail - the cup from which Jesus last drank - in order to save their society. For Bacon, the scientist would act as the quest knight and save the wartorn society of Western Europe, transforming it into an earthly Paradise. ${ }^{13}$ To do so, Bacon also drew on the Christian understanding of divinity as an intellectual, masculine God, as opposed to the superstitious Earth
Mother goddess of "pagans." So, scientists would "torture" Nature into revealing her secrets so that humans could exercise their intellects and reconstruct the world to produce a new world ordered for our benefit. ${ }^{14}$ Bacon's myth provided the fantasy of order and control that Western Europe desperately needed, after a century-and-a-half of religious warfare.

Descartes drew on the Church's teachings that God was a rational creator who wanted man to understand his creation. For Descartes, science should discover the truth about our world, focusing on what the scientist could know with certainty. ${ }^{15}$ In his efforts to do so, he would divide the world into passive matter, subject to God's Laws of Nature, and human mind. Most of the world, as passive matter, was therefore available for humans, through the power of their minds, to transform society as they learned more about these Laws of Nature. Combined with Bacon's philosophy, Cartesian thought provided the symbolic order that could promise the peace and certainty those who'd lived through the religious wars so desperately desired. Moreover, this cosmology justified the political system, as the ruler of Hobbes' Leviathan became the social equivalent of God, the ultimate cause of all events and the protector of the people, who, knowing they would be protected, could be as passive as Descartes' dead matter. ${ }^{16}$

This cosmology proved remarkably successful. With it, scientists could work hand-in-hand with the increasingly powerful commercial class. Just as Bacon had suggested, scientists revealed Nature's secrets, and, with the machine technology that became possible, the commercial class remade society. Largely because of this cosmology, food production has increased geometrically, contagious disease has largely been eliminated, and literacy rates have skyrocketed. Combined with the successes of science, especially in the discoveries of Lyle in Geology and Darwin in Evolution, God became a hypothesis that people could do without. And without God, the Western cosmology 
would increasingly become dominated by scientific materialism. The role of God would be replaced, first, by "Nature," whose now-anonymous laws moved all living things into action, and, then, by the Market and Adam Smith's Invisible Hand. ${ }^{17}$

And that is largely the cosmology of scientific materialism, Wilson's evolutionary epic, which rules today. For me, the problem with this cosmology - the problem that Zakariya points to over and over - isn't the story it tells. As long as we acknowledge that the story is a model - our best guess given what we know today - rather than the "truth," the story of the Big-Bang-to-the-present can serve the purposes that cosmologies have throughout human history. The problem is the often-unacknowledged assumptions built into the narrative, which, in many ways, have created existential challenges as great as those that precipitated the creation of this cosmology, ${ }^{18}$ including global warming and the possibility of a mass extinction of life on Earth.

Ironically, thirty years ago, the same science that Sagan celebrated in his 1980 TV series Cosmos, was predicting that global warming would be generating the sort of dramatic events we've been experiencing over the last year. Except that the intensity of global warming's effects has outstripped those predictions. And, yet, while scientists, who learned their style of knowing the world from the current cosmology, have been creating a series of technologies to ameliorate those effects, only a relative few of those technologies have been widely implemented, and the use of fossil fuels, the deforestation of the Amazon, and the consumption of animal protein, all of which scientists agree are making extreme warming more likely, are all increasing. I'm convinced that one of the major factors that has enabled the politicians and corporate executives, who had the power to make the changes that likely would have reduced the danger to all of us to ignore those decades-old warnings, is almost certainly the very cosmology that Sagan's Cosmos celebrated.
In this way, the same cosmology that has taught us in the West how to map the heavens, send people to walk on the moon, and double human life expectancy may well have increased the likelihood of the most extreme events resulting from global warming. How all this happened demands a much longer explanation than I can even begin to give in this book review. People who would like to examine it in depth would do well to read Latour's Facing Gaia. But one element of it is central for those of us who believe that the Big History origin story can become an effective cosmology for the twenty-first century.

Grounding this narrative in scientific materialism seems to have created a mindset that treats the world around us as a cornucopia to be exploited without considering the consequences. Remember, any cosmology will provide people in its society a way to think about everything in the world around them. The cosmological narrative as told through scientific materialism insists that our world is composed of independent "things," chunks of passive, dead matter, responding deterministically to the universal Laws of Nature. Only human mind has agency in this world. And the task of the scientist is to torture nature until she reveals her secrets so that we humans can rebuild the world for our purposes.

So, if the concept of cosmologies I've been examining is accurate, then we would expect corporate managers and executives to behave exactly as they have. After all, the cosmology of scientific materialism views the world as a collection of separate things that exist so that we humans can use them for our own ends. Moreover, they are distinct and come together only under the pressure of outside forces. How then can we expect people who accept this cosmology to think in terms of the highly interdependent processes, such as the damage that logging in the Amazon does to the Earth's ability to process $\mathrm{CO}_{2}$ ? If we want people throughout our economic systems to understand the 
complex processes that are making global warming look increasingly dangerous, we need a better version of our cosmology.

The point I want to make is that for those of us in IBHA, who believe that our origin story can be a cosmology for the $21^{\text {st }}$ Century, exploring how best to present this narrative is one of the most important things we can do, as members of the organization. Fortunately (or unfortunately if you prefer), the summer of 2019 has made the urgency of acting to mitigate global warming unavoidable. How, then, can we present our narrative in a way that will encourage people to think in ways that will avoid the pitfalls that the scientific materialist narrative has created?

This question deserves a far longer answer than I can provide here. But one possibility has already received some attention. The approach here is to replace the assumptions of scientific materialism with those of the worldview that has been emerging through most of the $20^{\text {th }}$ Century. This worldview sees the world as far more interconnected, full of agents that are continually changing to adapt to shifts in their environments, always with the possibility that even the smallest change can set off a cascade of adaptation. ${ }^{19}$ Because it is so full of agency and interconnection, it is a world where the future is constrained, rather than determined by the past.

My hope is that we in Big History will begin a far more rigorous discussion of our origin story/ cosmology and how it can evolve to best serve its purpose. In a way, Zakariya's title thus seems ironic: For as the conditions in our world shift, so must our cosmology, suggesting that A Final Story is really impossible. For anyone who wants to participate in this discussion, Zakariya's book provides the solid historical background that can help us examine whether it does make sense to replace the assumptions of scientific materialism with those of the new model. Too much is at stake, for us and our grandchildren, to turn away from this task.

\section{Endnotes}

${ }^{1}$ David Christian, Maps of Time: An Introduction to Big History, (Berkeley, CA: University of California Press, 2004), 3.

2 David Christian, Origin Story: A Big History of Everything (New York: Little, Brown and Co, 2018), ix-x.

${ }^{3}$ Pedro G. Ferreira, The State of the Universe: A Primer in Modern Cosmology (London: Orion Books, 2007), 13.

${ }^{4}$ Joseph Campbell, Pathways to Bliss: Mythology and Personal Transformation (Novato, CA: New World Library, 2004), 8.

${ }^{5}$ E.O. Wilson, as quoted in Nasser Zakariya, A Final Story: Science, Myth \& Beginnings (Chicago: University of Chicago Press, 2017), 300.

${ }^{6}$ Christian, Origin Story, 8 (author's emphases).

${ }^{7}$ Ferreira, The State of the Universe, 10 (my emphasis).

${ }^{8}$ John Knight Lundwall, Mythos and Cosmos: Mind and Meaning in the Oral Age (Pleasant Grove, UT: C\&L Press, 2015).

${ }^{9}$ Jean Bottéro, Religion in Ancient Mesopotamia, trans., Terresa Lavender Fagan (Chicago: University of Chicago Press, 2001).

${ }^{10}$ Donald Harman Akenson, Surpassing Wonder: The Invention of the Bible and the Talmuds (Chicago: University of Chicago Press, 2001).

${ }^{11}$ Stephen Toulmin, Cosmopolis: The Hidden Agenda of Modernity (Chicago: University of Chicago Press, 1990).

${ }^{12}$ Edward Dolnick, The Clockwork Universe: Isaac Newton, the Royal Society \& the Birth of the Modern World (New York: HarperCollins, 2011).

${ }^{13}$ Michael Allen Gillespie, The Theological Origins of Modernity (Chicago: University of Chicago Press, 2009).

${ }^{14}$ Mary Midgley, Science as Salvation: A Modern Myth and its Meaning (London: Routledge, 1992).

${ }^{15}$ Gillespie, The Theological Origins of Modernity; Toulmin, Cosmopolis.

16 Toulmin, Cosmopolis; Bruno Latour, Facing Gaia: Eight Lectures on the New Climate Regime, trans., Catherine Porter (Cambridge: Polity Press, 2017). 
${ }^{17}$ Latour, Facing Gaia.

${ }^{18}$ Mary Midgely, Science and Poetry (London: Routledge, 2001); Latour, Facing Gaia; Lisa H. Sideris, Consecrating Science: Wonder, Knowledge, and the Natural World (Oakland, CA: University of California Press, 2017).

19 Two of the most interesting treatments of this new worldview are those of Nobel Laureate in Physics Robert Laughlin's A Different Universe: Reinventing Physics from the Bottom Down (New York: Perseus Books, 2005), and astrophysicist Lee Smolin's The Life of the Cosmos (New York: Oxford University Press, 1997). Both Sideris' Consecrating Science and Latour's Facing Gaia explore some of the possibilities of applying this worldview to the cosmological narrative. 